\title{
The age and origin of the Straits of Singapore
}

\author{
M.I. Bird ${ }^{\mathrm{a}, *}$, W.C. Pang ${ }^{\mathrm{b}}$, K. Lambeck ${ }^{\mathrm{c}}$ \\ ${ }^{\text {a }}$ School of Geography and Geosciences, University of St. Andrews, St. Andrews, Fife, KY16 9AL, Scotland, UK \\ b Tropical Marine Science Institute, National University of Singapore, 14 Kent Ridge Road, Singapore, 119223, Singapore \\ ${ }^{c}$ Research School of Earth Sciences, Australian National University, Canberra, A.C.T. 0200, Australia
}

Received 13 June 2005; received in revised form 3 March 2006; accepted 5 May 2006

\begin{abstract}
Consideration of the Quaternary stratigraphy, sea-level history and detailed bathymetry of the Straits of Singapore suggests that a marine connection between the Indian Ocean and South China Sea through the Straits may not have existed until the last interglacial period (oxygen isotope stage; OIS-5e). After this time, a tenuous connection may have also existed during stages 5a and $5 \mathrm{c}$, as well as possibly $5 \mathrm{~b}$. The geomorphologic evidence is consistent with flow from west to east during these periods (the opposite direction to modern net flow), along a narrow palaeochannel that can be traced across the floor of the modern straits. Strong currents flowing through the Straits at these times are likely to have been responsible for scouring the $204 \mathrm{~m}$ 'overdeepened' basin known as the Singapore Deeps, and a similar $102 \mathrm{~m}$ deep basin south of the southern outfall of the Riau Straits. The evidence suggests that the region has been undergoing down-warping at a rate of 0.06 to $0.19 \mathrm{~mm} /$ year since the beginning of the last interglacial period, and the most likely value is at the lowest end of this range. While a more precise estimate of this rate will require further study, it is likely that the Singapore Straits has not been acted as a significant barrier to migration from mainland Asia to emergent areas of the Sunda Shelf for most of the Quaternary.
\end{abstract}

(C) 2006 Elsevier B.V. All rights reserved.

Keywords: Sea-level; Quaternary; Palaeoenvironments; Biogeography

\section{Introduction}

The Straits of Singapore define the southernmost modern limit of contiguous Southeast Asia, running between Singapore and Peninsular Malaysia to the north and the Indonesian Riau Archipelago to the south. The Straits provide the northernmost connection between the South China Sea and Pacific Ocean to the east and the Indian Ocean, via the Straits of Malacca, to the west (Chua et al., 2000; Moreton and Blackmore, 2001).

\footnotetext{
* Corresponding author. Tel.: +44 1334 463928; fax: +44 1334 463949.

E-mail address: Michael.bird@st-andrews.ac.uk (M.I. Bird).
}

Modelling has suggested that 0.1 to $0.2 \mathrm{~Sv}$ of water is currently transported from east to west (including water entering the Straits of Malacca from the Java Sea) forming a minor component of the Indonesian Throughflow (Wannasingha et al., 2003).

During interglacial periods of high sea-level, such as today, the Straits constitute the first barrier to the dispersal of many species, including pre-historic humans and megafauna, between the Indochinese mainland and insular Southeast Asia. In glacial times, global eustatic sea-level was lowered by around 130 m (e.g. Lambeck and Chappell, 2001), exposing the continental shelf south and east of the Malaysian Peninsular as the single continent of Sundaland 
(Hanebuth et al., 2000; Lambeck, 2001). One of the palaeo-Sunda Rivers, an extension of the modern Kampar River, is considered to have drained from Sumatra, through the Straits of Singapore to the South China Sea during these times (Molengraaff, 1921).

The land bridge across the Straits of Singapore was the last of the land bridges between the main islands of insular southeast Asia to be severed during periods of rising sea-level and the first to be exposed during periods of falling sea-level. Thus the timing and duration of exposure of the land bridge has important implications for the migration of species through the region. Based on modern bathymetry, the straits would have flooded across sills to the east and west when sealevel reached approximately $-30 \mathrm{~m}$. In this context, we use the term 'sill' to describe the lowest point on a modern inter-basin or inter-catchment divide, not a feature cut to bedrock, and hence the above estimate does not take into account the thickness of Holocene marine sediments that may have accumulated on the sills, or vertical tectonic movements that may have occurred.
Hill (1968) first pointed to the presence of an 'overdeepened' basin (up to $204 \mathrm{~m}$ deep and $\sim 1 \mathrm{~km}$ in diameter) in the centre of the Straits, called the 'Singapore Deeps' (Fig. 1). Immediately west of this point water flow is constricted to an opening $<5 \mathrm{~km}$ wide, between the bedrock highs comprising St. John's Island to the north and Batu Berhenti lighthouse/Pulau Sambo to the south. Hill (1968) concluded that the Deeps occupy a structural depression that resulted from 'a small graben or cross-faulting' including movement along a fault zone running south-east from Singapore, to Batam in Indonesia (Fig. 1). An additional possibility is that the Deeps represents an impact feature but in the absence of any evidence that this might be the case, tectonism continues to offer the most reasonable explanation. However, this provides no explanation for the persistence of a closed basin in the Straits of Singapore that is almost $100 \mathrm{~m}$ lower than the lowest base level for river incision in the region during the Quaternary.

It is the purpose of this paper to examine the Quaternary history of the Straits of Singapore in order to (1) explain how the unusual morphology of the Straits

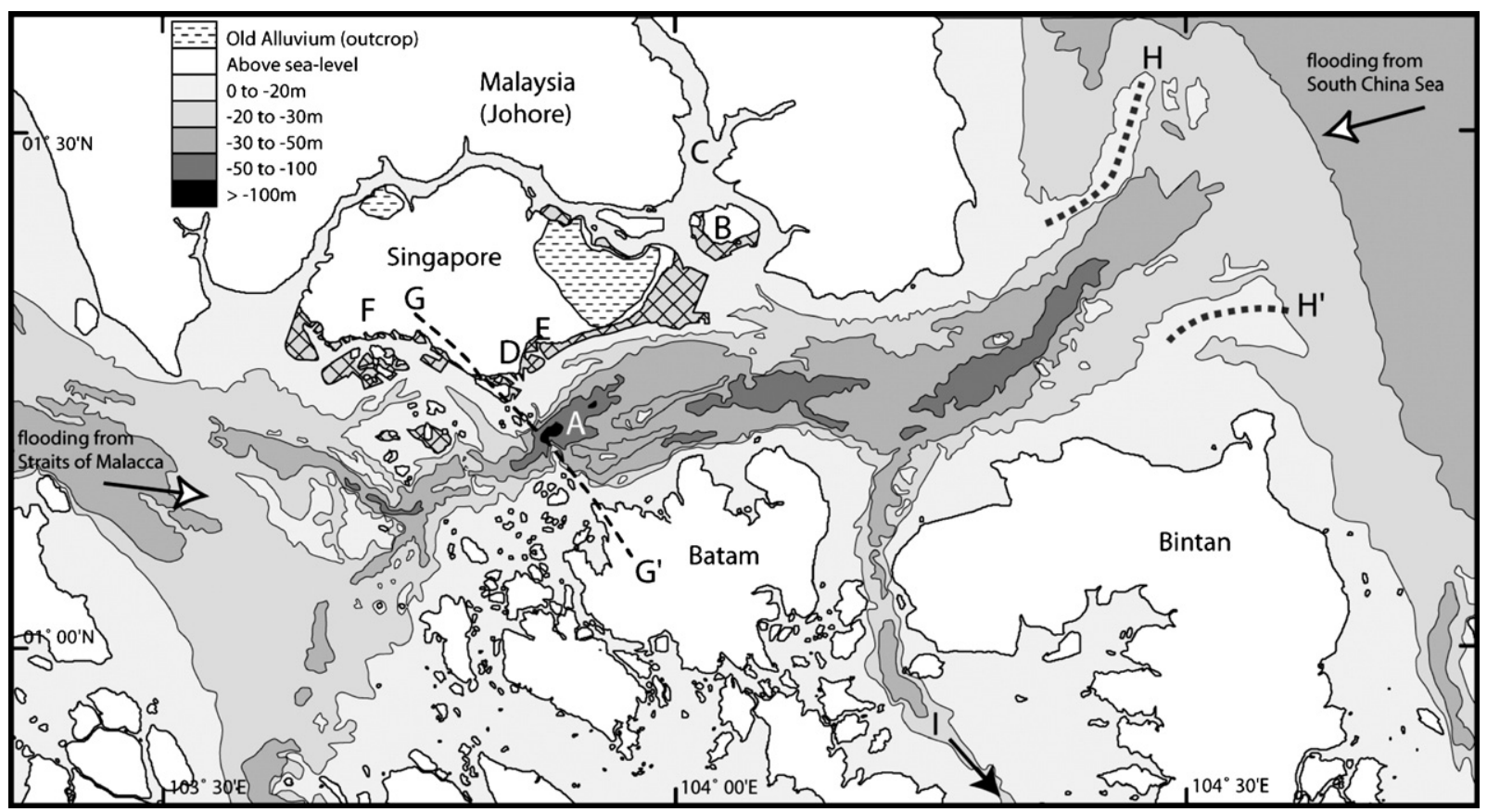

Fig. 1. General features of the Straits of Singapore and locations mentioned in the text. General bathymetry from Admiralty Chart 2403 'Singapore Straits and Eastern Approaches'. Reclaimed areas in Singapore indicated by cross-hatching. Individual features as follows - A: The Singapore Deeps (maximum depth 204 m, B: Pulau Tekong, C: Johore River, D: Singapore Central Business District, E: Bedok, F: Jurong; G and G': Fault inferred by Hill (1968) running from Kent Ridge in Singapore through St. John's Island, Pulau Sambo and Batam; H and H': splays of sediment at eastern end of Singapore Straits, as discussed in the text, I: Riau Strait between Bintan and Batam, with arrow indicating direction to overdeepened basin $104 \mathrm{~m}$ in depth at the southern exit to the Riau Strait. 
has developed, (2) estimate the likely times and durations of exposure of the land bridge across the Straits and (3) evaluate the implications of the above for the Quaternary tectonic and palaeoenvironmental history of the region.

\section{Quaternary sediments of the Straits of Singapore}

The bedrock into which the Straits are cut is dominated by shales, sandstones and conglomerates of the Late Triassic to Early Jurassic Jurong Formation (terminology of PWD, 1976 is used throughout), and may in part also be granitic, as granites outcrop along the northern coasts of Bintan and Batam, immediately south of the Straits. The oldest Quaternary sediments in regions adjacent to the Straits are the deeply weathered, highly consolidated but not lithified fluviatile sediments of the Old Alluvium (Gupta et al., 1987). These sediments are widely distributed in peninsular Malaysia and Riau Archipelago, both onshore and offshore. Batchelor (1988) suggested from palaeomagnetic dating that the Old Alluvium was deposited predominantly during the Matuyama reversed interval $(0.78-2.58 \mathrm{Ma})$ and thus dates from late Pliocene-early Pleistocene times. On mainland Singapore, the Old Alluvium is considered to be at least $50 \mathrm{~m}$ in thickness and outcrops across much of the eastern part of the island. It also occurs widely beneath later Quaternary sediments in the southeast of the island and offshore between Singapore and Johore to the south of Pulau Tekong. The Old alluvium has been deeply incised by old river channels, with the maximum recorded depth of incision being to 90 $95 \mathrm{~m}$, south of Pulau Tekong, along what is inferred to be a southeasterly trending palaeochannel of the Johore River (CCOP, 1980).

The earliest marine sediments in Singapore are represented by the Lower Marine Clay (LMC) member of the Kallang Formation, a homogeneous green-grey clay with occasional macroscopic fragments of shell and organic detritus (PWD, 1976). This unit is not exposed in outcrop, but underlies much of the Singapore central business district, Jurong and areas offshore to the south and east of the mainland. The thickness of unweathered LMC is variable but is commonly 10 to $20 \mathrm{~m}$ thick, with the upper 2-3 $\mathrm{m}$ intensely weathered to produce a mottled 'stiff clay'. The age of the LMC has not been directly determined, however only two marine sequences, separated by the 'stiff clay' palaeosol, have ever been reported despite the coring of thousands of sites across Singapore over the last few decades in support of construction and tunnelling projects. This strongly suggests that the unit was deposited during the last interglacial (LIG; $\sim 125,000$ years ago), with the sediments exposed and weathered during the last glacial period (OIS-4 to OIS-2) to produce the 'stiff clay' and then covered by the Upper Marine Clay (UMC; see below) after post-glacial sea-level rise.

The LMC has been recorded to depths of at least $50 \mathrm{~m}$ below sea-level and the highest reported occurrence of the LMC is $-4 \mathrm{~m}$ in Bedok (Pitts, 1983), although the latter claim is exceptional and cannot now be verified. The 'stiff clay' and LMC deposits are usually lower than -8 to $-9 \mathrm{~m}$ and, most commonly, the stiff clay forms a sub-horizontal unit that lies about $15 \mathrm{~m}$ below modern sea-level. The stiff clay has been observed as deep as $28 \mathrm{~m}$ below sea-level in the downtown area (PWD, 1976) and $30 \mathrm{~m}$ below sealevel in the area of the Pulau Tekong land reclamation works (Tan et al., 2002).

The Upper Marine Clay (UMC) is also a member of the Kallang Formation. It is similar in characteristics to the LMC and was deposited after the most recent flooding of the Straits (Hanebuth et al., 2000) that followed the last glacial maximum (LGM; 20,000 years ago). It often directly overlies the stiff clay developed on the LMC but sometimes overlies a thin mangrove peat deposited on the LMC during the initial stages of the post-LGM marine transgression. The highest recorded occurrence of the UMC is $1.8 \mathrm{~m}$ above sea-level (PWD, 1976), having accumulated above modern mean sealevel during and after a mid-Holocene sea-level highstand of approximately $+2.5 \mathrm{~m}$ around 6000 years ago (Hesp et al., 1998; Geyh et al., 1979). The UMC is widely distributed beneath the Central Business District and Jurong, often infilling incised channels cut in LMC or Old Alluvium during the last glaciation (PWD, 1976). The UMC continues to accumulate offshore.

\section{Experimental methods}

Raw bathymetry data was extracted from commercial raster navigation charts and electronic navigation charts published from 1998 to 2003 by Maritime Port Authority of Singapore. Linear interpolation using Delaunay triangulation was employed to produce a gridded bathymetry of $250 \mathrm{~m}$ resolution. Contours were generated from the gridded bathymetry using the default contouring function of the mathematical analysis and visualization software, MatLab.

Palaeo sea levels for the Singapore Strait, a farfield location, have been estimated on the assumption that any change is the result of the eustatic change and its concomitant glacio-hydro-isostatic contribution when 
the large ice sheets waxed and waned during successive glacial cycles. The formulation used here for the isostatic components has been most recently described in Lambeck and Johnston (1998) and Lambeck et al. (2003). The estimates of the eustatic change during the last glacial cycle, from observational evidence of sealevel change corrected for the local isostatic signals, are from Lambeck and Chappell (2001) and Lambeck et al. (2002). For sites far from the former high-latitude ice sheets the principal departure from eustasy is caused by the temporal and spatial variation of the ocean load as water is exchanged with the ice sheets and the model predictions are insensitive to details of how the ice is distributed between the principal ice sheets, provided that the total ice volumes are consistent with the eustatic change. The earth response functions used here correspond to values found to be appropriate for stable continental margins (cf. Lambeck et al., 2002). The predictions for the last glacial cycle show a slight dependence on the ice history of the previous cycle and to allow for this the proxy sea-level curve from the marine sediment $\delta^{18} \mathrm{O}$ record of Waelbroeck et al. (2002) has been used. Model ice volumes during the LIG are less, by $2.5 \mathrm{~m}$ equivalent sea level (i.e. sea-level during the LIG was $2.5 \mathrm{~m}$ higher) than during the Late Holocene.

\section{Results}

High-resolution bathymetry of the Straits is shown with a contour interval of $10 \mathrm{~m}$ in Fig. 2, revealing several features not immediately apparent from the navigation charts. The Singapore Deeps is visible as an oval depression east of an inferred fault line between St. John's Island and Batu Berhenti lighthouse, but also evident is a narrow canyon approximately $2 \mathrm{~km}$ long and several hundreds of metres wide that is incised about $40 \mathrm{~m}$ below the general level of the seafloor
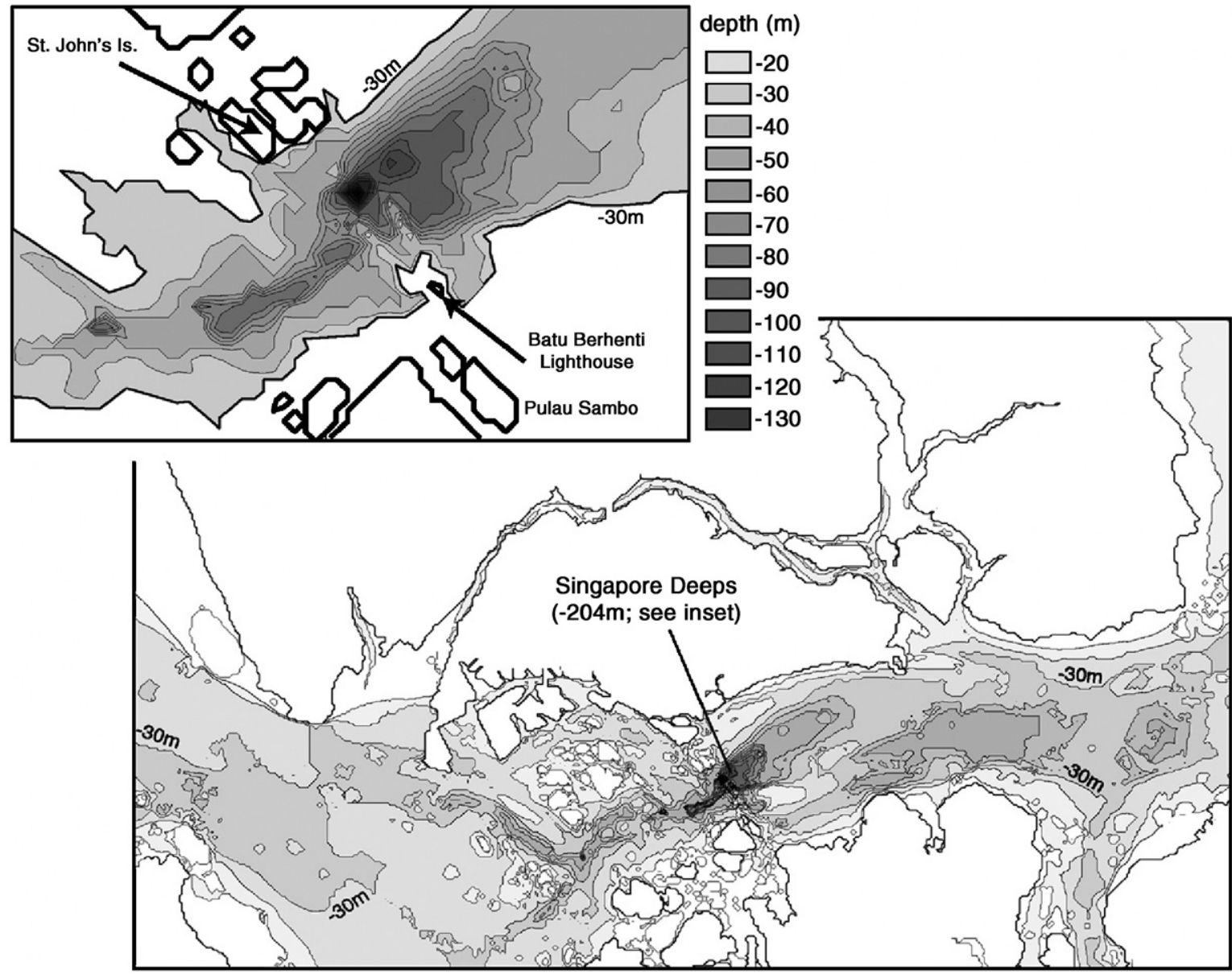

Fig. 2. High-resolution bathymetry of the Straits of Singapore, contoured at $10 \mathrm{~m}$ intervals, with inset of the Singapore Deeps. Distance from St. John's Island to Batu Berhanti lighthouse is $5 \mathrm{~km}$. For location and general features, see Fig. 1. 
immediately west of, and running into, the Singapore Deeps (see inset of Fig. 2). Also evident is a much larger palaeochannel that is best defined by the $-30 \mathrm{~m}$ isobath running from east to west through the Straits. This channel is generally incised by 10 to $30 \mathrm{~m}$ into the much flatter ocean floor west of the Deeps, but opens out into a much broader feature east of the Deeps before narrowing again towards the South China Sea. A further comparatively deep channel, averaging $\sim 30 \mathrm{~m}$ deep also runs north-south through the Riau Strait between Pulau Bintan and Pulau Batam. This channel ultimately empties into the South China Sea in the vicinity of another over-deepened basin $(-102 \mathrm{~m})$ at $0^{\circ} 35^{\prime} \mathrm{N}$ and $104^{\circ} 25^{\prime} \mathrm{E}$.

\section{Discussion}

Consideration of the detailed bathymetry now available for the Straits of Singapore and the Quaternary sedimentary history of the region allow several inferences to be drawn regarding the likely origin and evolution of the Straits of Singapore. As discussed by Hill (1968) it seems likely that the depression that forms the Singapore Deeps had an initially tectonic origin, with the strata to the east of the fault running from St. John's Island to Pulau Sambo, downthrown relative to strata on the west. The Old Alluvium was deposited by braided rivers flowing approximately south (Gupta et al., 1987) and, given the modern distribution of deposits of Old Alluvium immediately north of the Deeps, it seems likely that the structural depression caused by faulting would have been filled by Old Alluvium if the depression had existed by the beginning of the Quaternary.

The observation that the Old Alluvium has been incised to $-90 \mathrm{~m}$ by the palaeo-Johore River suggests that while the Deeps may have been partly filled by Old Alluvium, down-warping, subsidence or down-faulting must have continued well into the Pleistocene to provide a local base-level for erosion to at least $90 \mathrm{~m}$ below modern sea-level. Given that the modern $90 \mathrm{~m}$ isobaths in the both South China Sea and Straits of Malacca are several hundreds of kilometres away, it is likely that the Deeps represented the terminus of a basin with internal drainage, receiving waters from the palaeo-Johore river to the north and also from the palaeo-Kampar River originating in Sumatra to the west. During periods of positive water balance in these catchments, this basin may have filled, but incision to $-90 \mathrm{~m}$ indicates that the basin was not full for at least part of this time (see Bird et al., 2005 for a review of the palaeoclimatic history of the area). Sediments associated with this palaeo-lake have either been subsequently eroded or are yet to be recognized.

The earliest marine sediments in the Straits are represented by the $\mathrm{LMC}$, of probable last interglacial age as discussed above. The absence of marine sediments older than the LIG, despite there having been periods throughout the Quaternary when eustatic sea-level was similar to the LIG, suggests that the elevation of the sills to east and west of the straits have been decreasing during the Quaternary, and were lowered to a level sufficient to allow marine incursions into the straits after the end of the OIS-7 ( $\sim 180,000$ years ago) and before the beginning of the last interglacial OIS-5e $(\sim 130,000$ years ago). As current sill heights both to east and west of the straits are $30 \mathrm{~m}$ below sea-level, the apparent rate of decrease in sill elevation is 0.14 $0.19 \mathrm{~mm} /$ year, however, the veracity of this estimate is difficult to assess.

On the one hand, erosion of the sills during periods when the straits were flooded may have lowered the elevation of the sills by a considerable but unknown amount (as discussed below), and/or OIS-7 interglacial sea-level may have been lower than that of OIS-5, and therefore too low to flood the Straits. On the other hand, the calculation above does not take account of the thickness of Holocene sediments that may have accumulated on the former sills since the last flooding of the straits in post-LGM times. In at least the case of the western sill, Holocene sedimentation may be significant as studies have demonstrated substantial transport of sand to the southeast in the Straits of Malacca, ultimately accumulating in the region of the probable western sill (Ma and Chan, 2004).

A better estimate for the rate of decrease in sill elevation can be calculated from the current height of the highest recorded LMC. Assuming that (i) LIG eustatic sea-level was $\sim 2 \mathrm{~m}$ above modern sea-level, (ii) an LIG highstand similar in elevation to that of the Holocene occurred $(+2.5 \mathrm{~m})$, and (iii) the highest modern elevation of LMC deposits is between $-4 \mathrm{~m}$ and $-8 \mathrm{~m}$, rates of lowering of $0.06-0.1 \mathrm{~mm} /$ year are indicated since the end of OIS-5e. This is best considered a maximum estimate as it is unlikely that the very highest (and thinnest) LMC deposits would have survived in recognizable form due to sub-aerial weathering, and also because such deposits as remain are likely to have had their upper surface lowered by post-depositional compaction.

While it is generally thought that the Sunda Shelf is 'stable' (e.g. Geyh et al., 1979; Tjia, 1992), support for the general conclusion that the area of the straits is subsiding or downwarping is provided by the absence of 
last interglacial shoreline features onshore in peninsular Malaysia and the Riau archipelago, despite probable LIG shoreline features being well-preserved elsewhere in insular southeast Asia, for example in Sarawak (Fitch, 1954) and Palawan (Maeda et al., 2004). Kudrass and Schlüter (1994) conclude from seismic stratigraphic evidence from the offshore Quaternary sediments in the Straits of Malacca that at least western peninsular Malaysia has been subsiding during the Quaternary. In addition, many relict shoreline features now 10-30 m below sea-level, and therefore unlikely to relate to interstadial sea-level highstands, have been reported from the Riau Archipelago (summarized in Tjia, 1970). Kamaludin (2003) has also suggested that differential crustal movements have occurred between the east and west coasts of peninsular Malaysia implying that vertical crustal movements are occurring in the region. These tectonic movements might be a result of the active subduction that is currently occurring west of Sumatra.

Consideration of the sea-level curve since the LIG (Fig. 3) indicates that a tenuous connection could have existed between the Straits of Malacca and the South China Sea, through the Straits of Singapore, for several periods of a few thousand years each since OIS-5e.
Assuming that the sill heights were between -19 and $-22 \mathrm{~m}$ after adjustment for the decrease in sill elevation at the post-LIG rate calculated above, the straits were almost certainly open for 1000-2000 years at 108,000 (OIS-5c) and 84,000 (OIS-5a) years ago and may have also been briefly connected around 100,000 (OIS-5b) years ago.

During these periods, the entire flow of water between the Indian Ocean and the South China Sea was forced along the narrow channel in the centre of the Straits of Singapore, with the major bedrock constriction immediately west of the Singapore Deeps constraining this flow to a channel $<5 \mathrm{~km}$ in width. Tidal flows off Cape Rachado in the modern Straits of Malacca, even when not constrained to flow through narrow openings, can reach $1.8 \mathrm{~m} \mathrm{~s}^{-1}$ and result in bottom scouring to depths of around $75 \mathrm{~m}$ (Kudrass and Schlüter, 1994). Therefore the erosive capacity of flows through the Straits of Singapore during periods of shallow connection was likely to have been considerable. Incision of the palaeochannel could have been initiated during the initial period of flooding in OIS-5e, continued as sealevel dropped at the end of OIS-5e and then potentially been renewed during subsequent periods of connection.

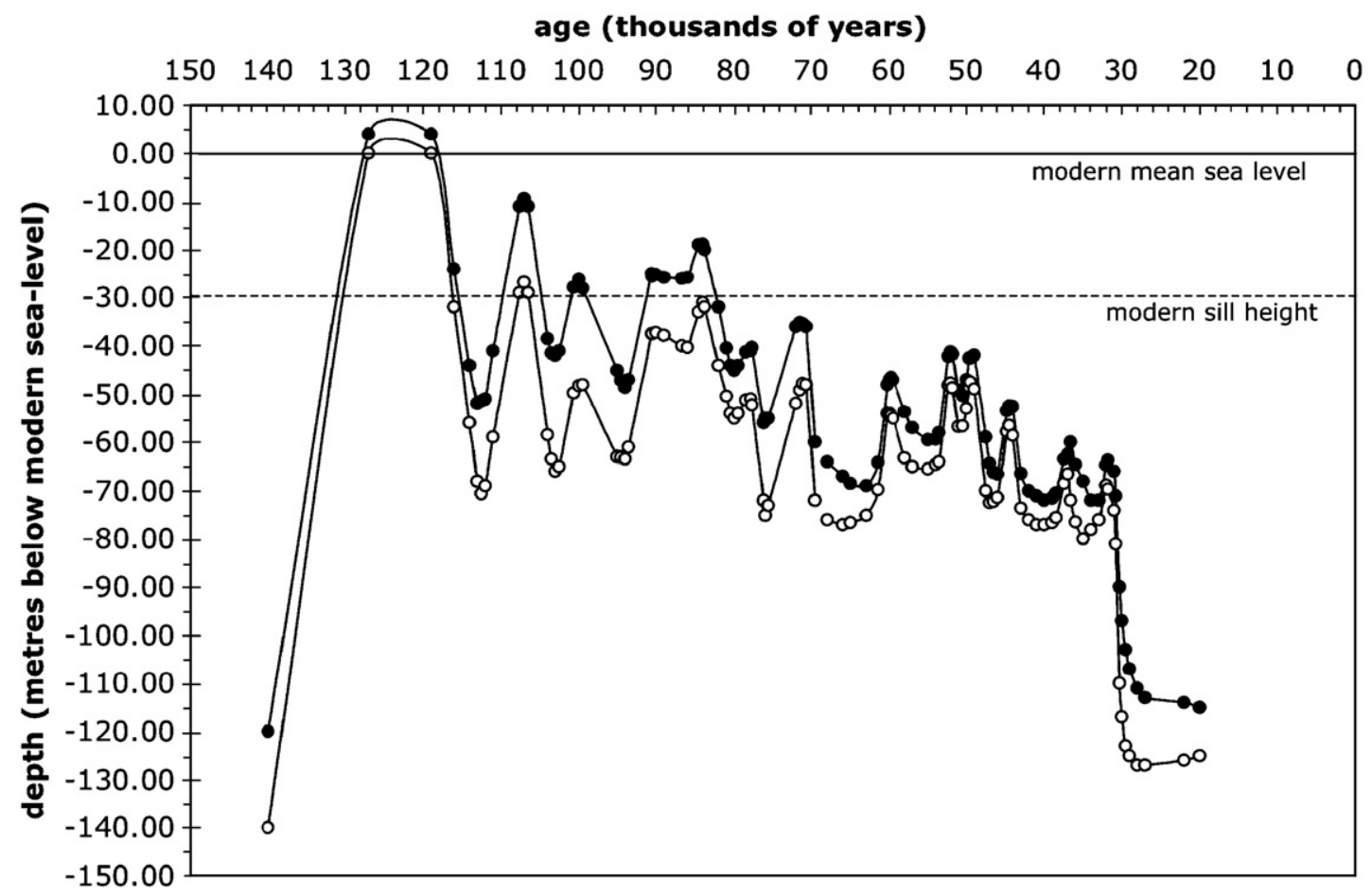

Fig. 3. Maximum (closed circles) and minimum (open circles) relative sea-level curves since the Last Interglacial Period for a farfield, low latitude site such as the Singapore Straits. These model uncertainties include the uncertainties in the modern data from which the total ice volumes have been estimated, as well as on the choice of model parameters and these have been discussed in Lambeck and Chappell (2001) and Lambeck et al. (2002). Typically they are about $\pm 2 \mathrm{~m}$ during the LIG, $\sim \pm 7 \mathrm{~m}$ during OIS-5d to $5 \mathrm{a}$ and $\sim \pm 5 \mathrm{~m}$ during OIS-4 and 3. 
To the east of the bedrock constriction, the structural depression formed by down-faulting in the early Quaternary was probably filled or partly filled by easily eroded unconsolidated fluvial and lacustrine sediments prior to flooding. These sediments were scoured out to $-204 \mathrm{~m}(\sim 170 \mathrm{~m}$ below the inferred sea-level at the time) to form the Singapore Deeps. Scouring occurred to bedrock to the west of the Deeps, forming a channel with a base generally varying between -40 and $-50 \mathrm{~m}$. To the east of the Deeps, a much wider basin was scoured to similar depths as in the west, exiting directly east to the South China Sea and also south via the narrow Riau Straits. Flow along the Riau Straits was significant enough to lead to scouring of another overdeepened basin to $-102 \mathrm{~m}$, where the Riau Straits open into the Java Sea.

The available geomorphic evidence points to the net flow during these periods of tenuous connection being from west to east. This evidence includes the deep scouring in the Deeps itself, east of the bedrock constriction, the over-deepened basin at the southern exit of the Riau Straits, and the arcuate splays of sediment that flank the outfall from the Straits of Singapore to the South China Sea (Fig. 1).

Sea surface heights in both the South China Sea and the Indian Ocean are currently strongly influenced by seasonal variations in monsoon winds. In the South China Sea, these can lead to seasonal variations of 20 $50 \mathrm{~cm}$ in the vicinity of Singapore (Shaw et al., 1999), with high sea-levels occurring during the southwest monsoon. Comparable variations occur in the Indian Ocean, but with highest sea-levels occurring during the northeast monsoon. Net annual water transport through the Straits of Singapore is currently from east to west during the northeast monsoon (Pang and Tkalich, 2003), with a possible monsoon-related seasonal reversal in flow during the southwest monsoon. The conclusion that net flow during periods of tenuous connection in OIS-5 were from west to east suggests the possibility that the southwest monsoon was weakened relative to the northeast monsoon, leading to strong sea-surface height-driven flows from the Straits of Malacca through the Straits of Singapore to the South China Sea and Java Sea.

\section{Conclusions}

The Quaternary geology and bathymetry of the Singapore Straits region is consistent with the conclusion that the Straits were first flooded during OIS-5e in response to long-term downwarping of the region. A narrow east-west palaeochannel, including the scour known as the 'Singapore Deeps', has been identified in the floor of the modern Singapore Straits. This channel was most likely incised during several periods of a few thousand years each, corresponding to OIS-5a, $5 \mathrm{~b}$ and 5c. During these times, a tenuous connection existed through this palaeochannel, forming the only connection between the Indian Ocean (via the Straits of Malacca) and the South China Sea. Strong currents capable of scouring unconsolidated sediments in the Singapore Deeps to a depth of $-204 \mathrm{~m}$ were generated in the channel by monsoon-driven sea surface height variations in the two ocean basins, with net flow of water from west to east.

The conclusion that the Singapore Straits region is undergoing downwarping, and that no marine connection existed through the Straits prior to the LIG has significant implications for the dispersal of organisms from mainland Southeast Asia to the Sunda Shelf. While dispersal was always possible during glacial periods of lowered sea-level, vegetation covering the region at these comparatively dry and cool times may not have been conducive to the migration of, for example, rainforest-dependent species (Bird et al., 2005). During interglacial periods, rainforest environments would have been available, but it has been assumed that high sealevels then posed a barrier to dispersal, including through the Straits of Singapore - the 'gateway' to the Sunda Shelf.

The most plausible interpretation of the evidence presented above suggests that prior to the LIG, there was no marine barrier to dispersal during interglacial periods in the Straits of Singapore. The areal extent of the downwarping affecting the Straits area cannot be determined, but evidence of drowned shorelines from Peninsular Malaysia in the north to the Java Sea islands of Bangka, Billiton and Singkep suggests that it might be widespread. This in turn suggests the possibility that no barriers to dispersal existed at all between Peninsular Malaysia and at least the islands of the Riau Archipelago and Sumatra prior to the LIG. The land bridge may only have been severed for short intervals of a few thousand years each during stage $5 \mathrm{a}$, $5 \mathrm{~b}$ and $5 \mathrm{c}$, and for $\sim 10,000$ years during OIS-5e, and then was not severed again until the beginning of the Holocene. This may explain in part how forestdependent species such as orangutans were able to disperse onto the Sunda Shelf in late Quaternary times (van den Bergh et al., 2001). Until the history of comparatively slow vertical movements of the Sunda Shelf have been better elucidated, it will not be possible to determine with confidence the timing or duration of the availability of the land bridges that 
connect peninsular Malaysia to emergent areas of the Sunda Shelf during times of lowered sea-level.

\section{Acknowledgments}

This research was partly funded by the Academic Research Fund Grant AcRF 19/01MB to MIB. Till Hanebuth provided a thorough and thoughtful review of the manuscript.

\section{References}

Batchelor, D.A.F., 1988. Dating of Malaysian fluvial tin placers. Journal of Southeast Asian Earth Sciences 2, 3-14.

Bird, M.I., Hunt, C., Taylor, D., 2005. Palaeoenvironments of insular Southeast Asia during the Last Glacial Period: a savanna corridor in Sundaland? Quaternary Science Reviews 24, 2228-2242.

CCOP, 1980. Results of a CCOP seismic profiler survey off the east coast of Singapore. CCOP Newsletter 7 (3), 1-8.

Chua, T.-.E., Gorre, I.R.L., Ross, A., Bernad, S.R., Gervacio, B., Ebarvia, M.C., 2000. The Malacca Straits. Marine Pollution Bulletin 41, 160-178.

Fitch, F.H., 1954. Tertiary to Recent sea-level changes and their effect on British Borneo physiography. Annual Report of the Geological Survey for the British Territories in Borneo. Government Printer Kuching, Sarawak, pp. 20-37.

Geyh, M.A., Kudrass, H.R., Streif, H., 1979. Sea-level changes during the late Pleistocene and Holocene in the Straits of Malacca. Nature 278, 441-443.

Gupta, A., Rahman, A., Wong, P.P., Pitts, J., 1987. The Old Alluvium and the extinct drainage system to the South China Sea. Earth Surface Processes and Landforms 12, 259-275.

Hanebuth, T., Stattegger, K., Grootes, P.M., 2000. Rapid flooding of the Sunda Shelf: a late Glacial sea-level record. Science 288, 1033-1035.

Hesp, P.A., Chang, C.H., Hilton, M., Ming, C.L., Turner, I.M., 1998. A first tentative Holocene sea-level curve for Singapore. Journal of Coastal Research 14, 308-314.

Hill, R.D., 1968. The Singapore "Deeps”. Malayan Nature Journal 21, 142-146.

Kamaludin, B., 2003. Mid-Holocene to Recent sea level changes in peninsular Malaysia. Geological Society of Malaysia Bulletin 46, 313-318.

Kudrass, H.R., Schlüter, H.U., 1994. Development of cassiteritebearing sediments and their relation to Late Pleistocene sea-level changes in the Straits of Malacca. Marine Geology 120, 175-202.

Lambeck, K., 2001. Glacial crustal rebound, sea levels and shorelines. In: Steele, J.H., Turekian, K.K., Thorpe, S.A. (Eds.), Encyclopedia of Ocean Sciences. Academic Press, pp. 1157-1167.

Lambeck, K., Johnston, P., 1998. The viscosity of the mantle: evidence from analyses of glacial rebound phenomena. In: Jackson, I. (Ed.), The Earth's Mantle. Cambridge University Press, Cambridge, pp. 461-502.
Lambeck, K., Chappell, J., 2001. Sea-level change through the last glacial cycle. Science 292, 679-686.

Lambeck, K., Yokoyama, Y., Purcell, T., 2002. Into and out of the Last Glacial Maximum: sea-level change during oxygen-isotope stages 3 and 2. Quaternary Science Reviews 21, 343-360.

Lambeck, K., Purcell, A., Johnston, P., Nakada, M., Yokoyama, Y., 2003. Water-load definition in the glacio-hydro-isostatic sea-level equation. Quaternary Science Reviews 22, 309-318.

Ma, P., Chan, E.S., 2004. Influences of wind and waves on the sediment transports in the Malacca Straits. Abstracts Joint 1st AOGS and 2nd APHW Conference, Singapore, July 5-9, 2004, p. 451.

Maeda, Y., Siringana, F., Omurab, A., Berdina, R., Hosonob, Y., Atsumib, S., Nakamurac, T., 2004. Higher-than-present Holocene mean sea levels in Ilocos, Palawan and Samar, Philippines. Quaternary International 115-116, 15-26.

Molengraaff, G.A.F., 1921. Modern deep-sea research in the East Indian archipelago. Geographical Journal 57, 95-121.

Moreton, B., Blackmore, G., 2001. South China Sea. Marine Pollution Bulletin 42, 1236-1263.

Pang, W-C., Tkalich, P., 2003. Modelling tidal and monsoon driven currents in the Singapore Straits. Singapore Maritime \& Port Journal 2003 151-162.

Pitts, J., 1983. The origin, nature and extent of recent deposits in Singapore. Proceedings International Seminar on Construction Problems in Soft Soils. 1st-3rd December, 1983, Singapore JP1-JP18.

PWD, 1976. Geology of the Republic of Singapore. Public Works Department. $79 \mathrm{pp}$.

Shaw, P.-.T., Chao, S-Y., Fu, L.-.L., 1999. Sea surface height variations in the South China Sea from satellite altimetry. Acta Oceanologica $22,1-17$.

Tan, T.S., Phoon, K.K., Lee, F.H., Tanaka, H., Locat, J., Chong, P.T., 2002. A characterisation study of Singapore Lower Marine Clay. In: Tan, T.S., Phoon, K.K., Hight, D.W., Leroueil, S. (Eds.), Characterisation and Engineering Properties of Natural Soils, 2-4, December 2002, Singapore: Vol. 1. Balkema, pp. 429-454. 2003.

Tjia, H.D., 1970. Quaternary shorelines of the Sunda Land, Southeast Asia. Geologie en Mijnbouw 49, 135-144.

Tjia, H.D., 1992. Holocene sea-level changes in the Malay-Thai Peninsula, a tectonically stable environment. Geological Society of Malaysia Bulletin 31, 157-176.

van den Bergh, G.D., Vos, J., Sondaar, P.Y., 2001. The late Quaternary palaeogeography of mammal evolution in the Indonesian archipelago. Palaeogeography, Palaeoclimatology, Palaeoecology 171, 385-408.

Waelbroeck, C., Labeyrie, L., Michel, E., Duplessy, J.C., McManus, J. F., Lambeck, K., Balbon, E., 2002. Sea-level and deep water temperature changes derived from benthic foraminifera isotopic records. Quaternary Science Reviews 21, 295-305.

Wannasingha, U., Webb, D.J., de Cuevas, B.A., Coward, A.C., 2003. On the indonesian throughflow in the OCCAM model. Abstracts EGS-AGU-EUG Joint Assembly Nice, France, 06-11 April 2003. 